\title{
Polycyclic Aromatic Hydrocarbons, Polychlorinated Biphenyls, and Metals in Ambient Sediment at Mussel Biomonitoring Sites, Puget Sound, Washington
}

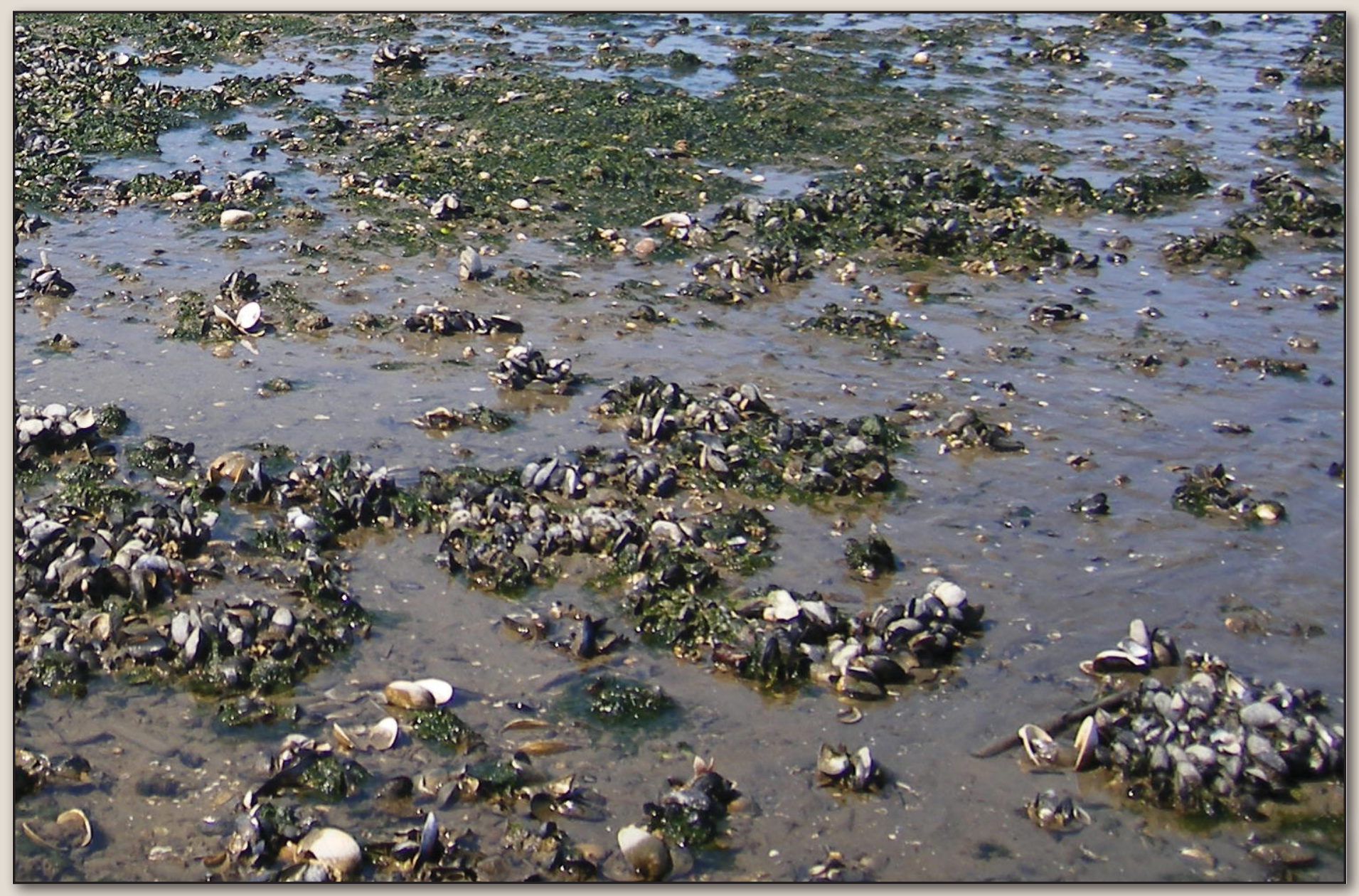

Open-File Report 2019-1087

U.S. Department of the Interior U.S. Geological Survey 
Cover. Photograph of native mussels and ambient sediment at the reference site, Penn Cove, Washington, on April 21, 2011. 


\section{Polycyclic Aromatic Hydrocarbons, Polychlorinated Biphenyls, and Metals in Ambient Sediment at Mussel Biomonitoring Sites, Puget Sound, Washington}

By Renee K. Takesue, Pamela L. Campbell, and Kathleen E. Conn

Open-File Report 2019-1087 


\title{
U.S. Department of the Interior DAVID BERNHARDT, Secretary
}

\author{
U.S. Geological Survey \\ James F. Reilly II, Director
}

U.S. Geological Survey, Reston, Virginia: 2019

For more information on the USGS - the Federal source for science about the Earth, its natural and living resources, natural hazards, and the environment-visit https://www.usgs.gov or call 1-888-ASK-USGS.

For an overview of USGS information products, including maps, imagery, and publications, visit https://store.usgs.gov.

Any use of trade, firm, or product names is for descriptive purposes only and does not imply endorsement by the U.S. Government.

Although this information product, for the most part, is in the public domain, it also may contain copyrighted materials as noted in the text. Permission to reproduce copyrighted items must be secured from the copyright owner.

Suggested citation:

Takesue, R.K., Campbell, P.L., and Conn, K.E., 2019, Polycyclic aromatic hydrocarbons, polychlorinated biphenyls, and metals in ambient sediment at mussel biomonitoring sites, Puget Sound, Washington: U.S. Geological Survey Open-File Report 2019-1087, 15 p., https://doi.org/10.3133/ofr20191087.

ISSN 2331-1258 (online) 


\section{Contents}

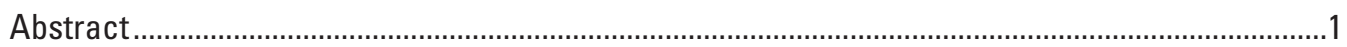

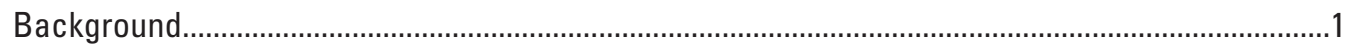

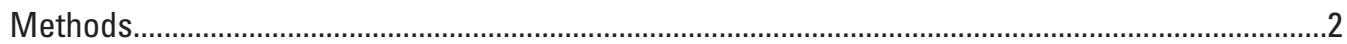

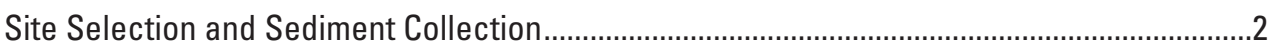

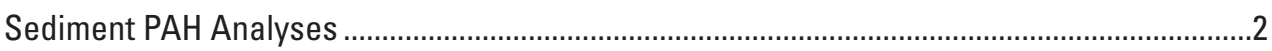

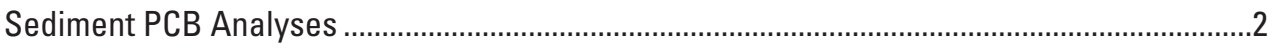

Sediment Inorganic Element Analyses ...............................................................................

Sediment Grain Size and Total Organic Carbon Analyses ........................................................

Sediment Quality and Caged Mussel Data ...............................................................................

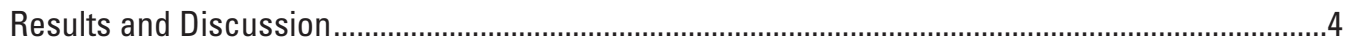

Sediment Grain-Size Distributions .......................................................................................

PAH Concentrations in Ambient Fine Sediment ......................................................................

Comparisons of PAHs and Diagnostic Ratios in Ambient Fine Sediment and Caged Mussels....7

PCB Contents of Ambient Fine Sediment................................................................................

Comparisons of PCBs in Ambient Fine Sediment and Caged Mussels ...................................9

Arsenic and Potentially Toxic Metals in Ambient Fine Sediment..........................................12

Arsenic and Potentially Toxic Metals in Ambient Fine Sediment and Caged Mussels...........12

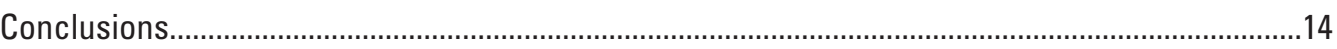

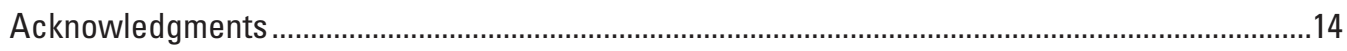

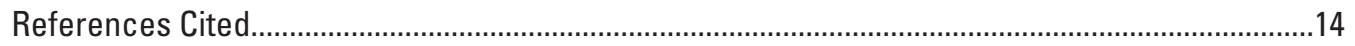

\section{Figures}

1. Map of the Puget Sound region, Washington State, showing study site locations..............3

2. Bar graphs showing sediment grain-size distributions as fractional weights for grain-size classes ........................................................................................................

3. Stacked bar graph showing concentrations of high and low molecular weight polycyclic aromatic hydrocarbons in ambient sediment...................................................

4. Bar graphs of individual polycyclic aromatic hydrocarbon concentrations in sediment and caged mussels at each study site .........................................................

5. Bivariate plot of diagnostic polycyclic aromatic hydrocarbon ratios in ambient sediment and caged mussels ...................................................................................

6. Plot showing the contribution of congeners to the total polychlorinated biphenyl concentration in fine nearshore sediment, February 2016 ...........................................11

7. Bar graph showing polychlorinated biphenyl concentrations in nearshore fine sediment and caged mussels in Puget Sound embayments and open shoreline sites

8. Bar graphs showing arsenic and potentially toxic metal contents in fine sediment at all study sites

9. Plots of potentially toxic element concentrations in ambient fine sediment versus caged mussels 


\section{Tables}

1. Names, abbreviations, sample types, collection dates, coordinates, and sediment characteristics of ten study sites sampled for this study..................................

2. Concentrations of polycyclic aromatic hydrocarbons in ambient sediment .......................6

3. Concentrations of polychlorinated biphenyls in fine nearshore sediment,

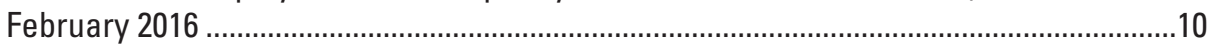

4. Contents of potentially toxic elements in fine sediment at caged mussel sites and Samish Bay. 


\section{Conversion Factors}

International System of Units to U.S. customary units

\begin{tabular}{|c|c|c|}
\hline Multiply & By & To obtain \\
\hline \multicolumn{3}{|c|}{ Length } \\
\hline centimeter $(\mathrm{cm})$ & 0.3937 & inch (in.) \\
\hline millimeter (mm) & 0.03937 & inch (in.) \\
\hline meter $(\mathrm{m})$ & 3.281 & foot $(\mathrm{ft})$ \\
\hline kilometer $(\mathrm{km})$ & 0.6214 & mile (mi) \\
\hline meter $(\mathrm{m})$ & 1.094 & yard (yd) \\
\hline \multicolumn{3}{|c|}{ Area } \\
\hline square centimeter $\left(\mathrm{cm}^{2}\right)$ & 0.001076 & square foot $\left(\mathrm{ft}^{2}\right)$ \\
\hline square meter $\left(\mathrm{m}^{2}\right)$ & 10.76 & square foot $\left(\mathrm{ft}^{2}\right)$ \\
\hline hectare (ha) & 0.003861 & square mile $\left(\mathrm{mi}^{2}\right)$ \\
\hline square kilometer $\left(\mathrm{km}^{2}\right)$ & 0.3861 & square mile $\left(\mathrm{mi}^{2}\right)$ \\
\hline \multicolumn{3}{|c|}{ Volume } \\
\hline liter $(\mathrm{L})$ & 33.81402 & ounce, fluid (fl. oz) \\
\hline liter $(\mathrm{L})$ & 2.113 & $\operatorname{pint}(\mathrm{pt})$ \\
\hline liter (L) & 1.057 & quart (qt) \\
\hline liter $(\mathrm{L})$ & 0.2642 & gallon (gal) \\
\hline cubic meter $\left(\mathrm{m}^{3}\right)$ & 264.2 & gallon (gal) \\
\hline cubic meter $\left(\mathrm{m}^{3}\right)$ & 0.0002642 & million gallons (Mgal) \\
\hline cubic centimeter $\left(\mathrm{cm}^{3}\right)$ & 0.06102 & cubic inch $\left(\mathrm{in}^{3}\right)$ \\
\hline $\operatorname{liter}(\mathrm{L})$ & 61.02 & cubic inch $\left(\right.$ in $\left.^{3}\right)$ \\
\hline cubic meter $\left(\mathrm{m}^{3}\right)$ & 35.31 & cubic foot $\left(\mathrm{ft}^{3}\right)$ \\
\hline cubic meter $\left(\mathrm{m}^{3}\right)$ & 1.308 & cubic yard $\left(\mathrm{yd}^{3}\right)$ \\
\hline \multicolumn{3}{|c|}{ Mass } \\
\hline $\operatorname{gram}(\mathrm{g})$ & 0.03527 & ounce, avoirdupois (oz) \\
\hline kilogram (kg) & 2.205 & pound avoirdupois (lb) \\
\hline
\end{tabular}

Temperature in degrees Celsius $\left({ }^{\circ} \mathrm{C}\right)$ may be converted to degrees Fahrenheit $\left({ }^{\circ} \mathrm{F}\right)$ as follows:

$$
{ }^{\circ} \mathrm{F}=\left(1.8 \times{ }^{\circ} \mathrm{C}\right)+32 .
$$

\section{Datum}

Horizontal coordinate information is referenced to the World Geodetic System standard of 1984 (WGS84). 


\title{
Acronyms and Abbreviations
}

\author{
DW dry weight \\ ERL effects range-low \\ ERM effects range-median \\ g gram \\ $\mu \mathrm{g} / \mathrm{g} \quad$ microgram per gram \\ $\mathrm{mg} / \mathrm{kg} \quad$ milligram per kilogram \\ MLLW mean lower low water \\ $\mu \mathrm{m} \quad$ micrometer \\ $\mathrm{mm} \quad$ millimeter \\ $\mathrm{ng} / \mathrm{g} \quad$ nanogram per gram \\ USGS U.S. Geological Survey \\ WASMS Washington State Sediment Management Standards \\ WDFW Washington State Department of Fish and Wildlife
}

\section{Chemical Symbols Used}

$\begin{array}{ll}\text { As } & \text { arsenic } \\ \text { BZP } & \text { benzo[g,h,i]perylene } \\ \mathrm{Cd} & \text { cadmium } \\ \mathrm{Cu} & \text { copper } \\ \mathrm{DBA} & \text { dibenzo[a, } h] \text { anthracene } \\ \mathrm{Hg} & \text { mercury } \\ \mathrm{Hg} & \text { total mercury } \\ \mathrm{HMW} & \text { high molecular weight } \\ \text { IDP } & \text { indeno[1,2,3-c,d]pyrene } \\ \mathrm{LMW} & \text { low molecular weight } \\ \mathrm{N} & \text { dinitrogen } \\ \text { OC } & \text { total organic carbon } \\ \mathrm{PAH} & \text { polycyclic aromatic hydrocarbon } \\ \mathrm{Pb} & \text { lead } \\ \mathrm{PCB} & \text { polychlorinated biphenyl } \\ \text { TC } & \text { total carbon } \\ \text { TIC } & \text { total inorganic carbon } \\ \mathrm{Zn} & \text { zinc }\end{array}$




\title{
Polycyclic Aromatic Hydrocarbons, Polychlorinated Biphenyls, and Metals in Ambient Sediment at Mussel Biomonitoring Sites, Puget Sound, Washington
}

\author{
By Renee K. Takesue, Pamela L. Campbell, and Kathleen E. Conn
}

\section{Abstract}

Caged mussels used as biomonitors can provide insights about ambient contaminant assemblages and spatial patterns, sources of contaminants, and contaminant exposure risks for consumers of wild and farmed mussels. This study explored the potential role of ambient sediment in the uptake of polycyclic aromatic hydrocarbons (PAHs), polychlorinated biphenyls (PCBs), and potentially toxic inorganic elements by caged mussels and complements findings from a Puget Soundwide stormwater-contaminant mussel-monitoring survey in Washington State. Total PAH concentrations in sediment normalized for total organic carbon were below levels of concern, and were highest at industrial and urban sites, similar to findings from the mussel monitoring survey. Liberty Bay and Eagle Harbor were the only sites at which PAH assemblages in sediment were highly correlated with those in mussels, possibly reflecting an uptake mechanism. At other sites, there were no consistent relationships between sediment and mussel PAH assemblages, concentrations, or body burdens. Diagnostic $\mathrm{PAH}$ ratios in sediment and mussels were indicative of PAHs sourced from petroleum combustion at Chuckanut Bay, a site adjacent to railroad tracks, and incomplete biomass/coal combustion elsewhere. There was a first-order relationship between sediment and mussel total PCB levels: PCBs were high in caged mussels at industrial sites that had high sediment PCBs. Total PCB concentrations in sediment were well below levels of concern and there were no distinctive PCB congener fingerprints indicative of different sources among sites. Mussels appeared to bioregulate tissue contents of As, $\mathrm{Cd}, \mathrm{Hg}_{\mathrm{T}}$, and $\mathrm{Zn}$, a process that could, in part, explain why the mussel monitoring survey found no correlations between tissue contents of these metals and impervious surface areas. In contrast, increases in mussel tissue contents of lead were correlated with those of sediments, showing nonbioregulation of lead that could contribute to the strong positive correlation found between mussel-tissue lead contents and impervious surface areas in a pilot study. In summary, ambient sediment appeared to be related to mussel uptake of lead and possibly copper at all sites, PCBs at industrial sites, and PAHs at Liberty
Bay, Eagle Harbor, and, to a lesser extent, Smith Cove. These findings indicate that resuspended bed sediment is one, but not the only, pathway that filter-feeding mussels are exposed to contaminants. Overall, PAHs, PCBs, As, and potentially toxic metals were low in intertidal bed sediment at the nine sites measured in Puget Sound in February 2016 and signify a low risk of sediment-bound contaminant exposure to mussels at those locations.

\section{Background}

Caged mussels are effective biomonitors of ambient contaminant assemblages because they ingest water and suspended particles and store contaminants from those carriers in body tissues (Wade and others, 1998). The Washington State Department of Fish and Wildlife (WDFW) deployed caged mussels from late October 2015 through early February 2016 as part of a Puget Sound-wide stormwater contaminant monitoring program (Lanksbury and others, 2017). Stormwater is a major pathway of contaminant delivery to nearshore waters of Puget Sound (Norton and others, 2011). Finegrained sediment deposits on the seabed are another large reservoir of legacy contaminants in Puget Sound (Barrick and Prahl, 1987), and can be resuspended by waves and tidal currents and ingested by filter-feeding organisms, such as mussels. Characterization of contaminants in ambient sediment and mussels can provide insights about contaminant uptake pathways and exposure risks for mussel consumers. Concentrations of contaminants in deep marine sediment in Puget Sound are generally below levels of concern, and longterm trends indicate constant or decreasing levels in many Puget Sound areas outside of industrial harbors (Dutch and others, 2009). Little is known, however, about the occurrence and concentrations of contaminants in nearshore sediment, where intertidal species, such as mussels, live. Nearshore sediment may be more directly impacted by anthropogenic activities, such as shoreline development and stormwater runoff of dissolved and particulate-bound contaminants, than deep marine sediment. The goals of this study were 
to characterize ambient nearshore sediment contaminant assemblages, concentrations, and potential sources at select sites where mussel cages were deployed in order to understand the potential contribution of resuspended bed sediment to contaminant body burdens of caged mussels. This study targeted the persistent organic pollutants polycyclic aromatic hydrocarbons (PAHs) and polychlorinated biphenyls (PCBs), the potentially toxic metalloid arsenic (As), and potentially toxic metals cadmium $(\mathrm{Cd})$, copper $(\mathrm{Cu})$, mercury $(\mathrm{Hg})$, lead $(\mathrm{Pb})$, and zinc $(\mathrm{Zn})$. Understanding the role ambient sediment plays as a source of contaminants to filter feeding mussels can shed light on one contaminant uptake pathway in nearshore food webs.

\section{Methods}

\section{Site Selection and Sediment Collection}

Eight caged mussel sites (see fig. 1) were selected from among 70 WDFW sites based on the criteria that sites had fine-grained, or muddy, ambient sediment (Chimacum Creek, Skunk Island, Liberty Bay, Eagle Harbor, Illahee State Park) and (or) that sites were in industrial or urban areas of interest (Smith Cove, Harbor Island, Seahurst Park). Mussel cages were deployed at 0 feet mean lower low water (MLLW). Ambient bed sediment (top 2 centimeters) was collected adjacent to eight mussel cages and at a ninth site in Samish Bay at low tide during February 5-9, 2016, at the end of a three-month-long mussel deployment. In Chuckanut Bay, sediment was collected in September 2015 at the north end of the bay, whereas the mussel cage was installed one month later in October 2015 at the tip of Clark's Point, 850 meters to the south. Although sediment was not collected in close proximity to the mussel cage, comparisons of potentially toxic elements in sediment and mussels were made for this site pair because fine-grained sediment delivered to the north part of the bay from Chuckanut Creek could be transported in suspension to the mussel site. Contaminants were characterized in sediment from Colony Creek in Samish Bay to allow comparison with those found in recently hatched forage fish collected nearby, and to represent contaminant assemblages from an agricultural watershed. Sediments for organic compound analyses were collected with stainless steel sampling tools and placed into pre-combusted glass jars. Sediment for PCB analysis was sieved to less than 63 micrometers $(\mu \mathrm{m})$ using a methanol-cleaned stainless steel sieve and Teflon spatula then stored in glass jars. Sediments for inorganic analyses were collected with acid-cleaned nonmetallic sampling tools and placed into wire-top plastic bags. Samples were stored and shipped frozen until analysis.

\section{Sediment PAH Analyses}

Eight of the ten samples were analyzed for PAHs; sediment from Seahurst Park and Harbor Island contained less than 3 percent fines and were thus omitted from the PAH analyses. Molecular composition of the organic fraction of sediment was determined by gas chromatography/ mass spectrometry at the U.S. Geological Survey (USGS) Organic Geochemistry Laboratory in Santa Cruz, California. Approximately 1-2 grams (g) of freeze-dried organic matter was extracted from bulk sediment by pressurized solvent extraction (using a Dionex accelerated solvent extractor). Samples were extracted with solvent mixtures of hexane:acetone (1:1) followed by dichloromethane:methanol (2:1). An internal standard (ortho-terphenyl), in addition to surrogate standards (acenaphthene-d10, phenanthrene-d10, chrysene-d12, perylene-d12; standards from ULTRA

Scientific), were added to samples prior to extraction. Prior to use, glassware was washed, solvent rinsed (methanol, hexane, and dichloromethane), and combusted at $450^{\circ} \mathrm{C}$ overnight. Blanks were run for the entire procedure, including extraction, solvent concentration, and purification. After evaporation of extracts to $\sim 5$ milliliters in volume utilizing a Zymark TurboVap evaporation concentrator, samples were loaded onto liquid chromatography columns for compound class separation. Each column was layered with $2.5 \mathrm{~g}$ of 5-percent deactivated alumina, $2.5 \mathrm{~g}$ of 62 silica gel and $5.0 \mathrm{~g}$ of 923 silica gel, which had previously been activated at $500{ }^{\circ} \mathrm{C}$ for 8 hours and then, in the case of the alumina, partly deactivated with ultrapure water ( 5 percent weight per weight). Two separate fractions were collected: F1-saturate (100 percent hexane eluent) and F2-aromatic (30 percent toluene, 70 percent hexane eluent), and reduced in volume under $\mathrm{N}_{2}$ to 1.0 milliliter. Extracts were analyzed by splitless injection onto an Agilent 6890 gas chromatograph interfaced to a Hewlett Packard 5973 mass spectrometer. The gas chromatograph oven program had an initial temperature of $90^{\circ} \mathrm{C}$, which was held for 4.0 minutes then ramped at $5{ }^{\circ} \mathrm{C}$ per minute to a final temperature of $310^{\circ} \mathrm{C}$ and held for 10 minutes. The capillary column (DB-5ms: 30-meter length, 0.25-millimeter ID with a $25-\mu \mathrm{m}$ phase thickness) was directly interfaced to the ion source of the mass spectrometer. Hexane instrument blanks and procedural sample duplicates were run every 10 samples. Compound identifications were made by comparison with known analytical standards and (or) published reference spectra. Concentrations of individual PAHs were calculated from the internal standard. Concentrations (in micrograms per gram $[\mu \mathrm{g} / \mathrm{g}])$ are reported normalized to organic carbon (OC) content of dry sediment.

The diagnostic PAH ratios fluoranthene : fluoranthene + pyrene and indeno[1,2,3-c,d]pyrene (IDP) : IDP + benzo[g,h,i] perylene (BZP) are indicative of PAHs sourced from liquid petroleum and incomplete combustion of petroleum and biomass and (or) coal (Yunker and others, 2002).

\section{Sediment PCB Analyses}

Nine sediment samples were analyzed for 209 PCB congeners (sediment from Chuckanut Bay was not analyzed) by U.S. Environmental Protection Agency Method 1668C by SGS AXYS Analytical Services Ltd. (Sidney, British 


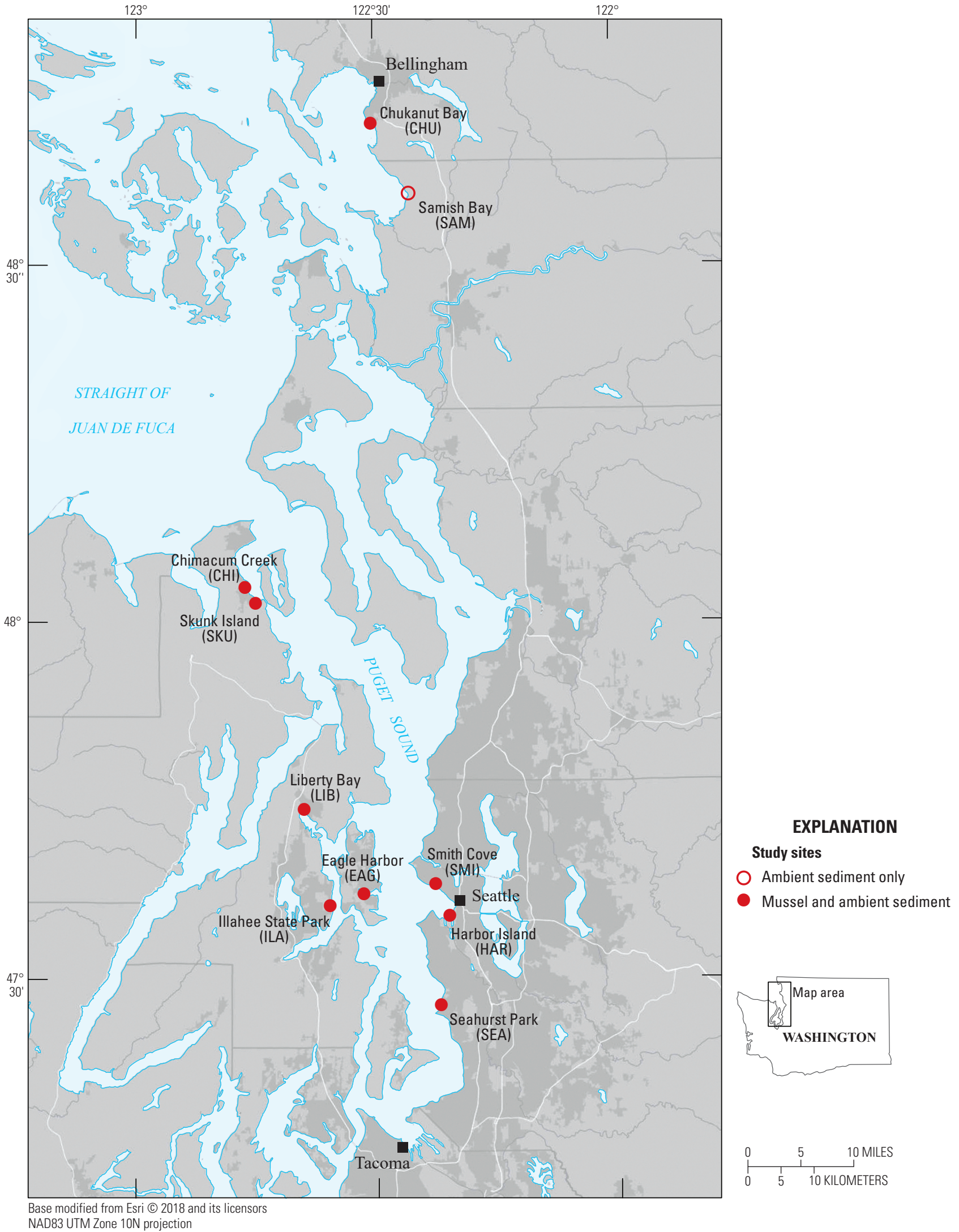

Figure 1. Map of Puget Sound region, Washington State, showing study site locations. 
Columbia). Briefly, samples were spiked with isotopically labeled analog compounds and internal standards, solvent extracted, and analyzed on a SPB-Octyl column coupled to a high-resolution mass spectrometer. Quantification was based on the presence of a chromatographic peak at least 2.5 times the background noise level, matching of retention time and ion abundance ratios against a known standard, and the isotope dilution/internal standard method, which corrects concentrations based on the percentage recovery of the surrogate. Detection limits were determined individually for every sample analysis run and ranged from 0.07 to 1.88 picograms per gram. Results were reported on a dry weight basis. Laboratory quality assurance and control measures included five-point calibration checks and laboratory blank, replicate, and spike samples to be run with every batch of 20 samples. A laboratory replicate analysis was performed on the Samish Bay sediment sample and the total PCB concentration (sum of 209 congeners) differed by less than 0.3 nanograms per gram $(\mathrm{ng} / \mathrm{g})$. Congener concentration was not included in the summed calculation if the result was less than three times the value measured in corresponding laboratory blank samples. Results were reviewed and approved by personnel at the U.S. Fish and Wildlife Service's Analytical Control Facility and the congener results with original lab qualifiers are stored in the Environmental Contaminants Data Management System.

\section{Sediment Inorganic Element Analyses}

Sediment was oven dried at $60^{\circ} \mathrm{C}$ and disaggregated with a mortar and pestle. Dry sediment was sieved in stainless steel sieves to obtain 2 grams of the fraction less than $63 \mu \mathrm{m}$ (fine), and sent to the USGS Central Mineral and Environmental Resources Science Center Analytical Chemistry Laboratory for determinations of $\mathrm{As}, \mathrm{Cd}, \mathrm{Cu}, \mathrm{Pb}, \mathrm{Hg}_{\mathrm{T}}$, and $\mathrm{Zn}$. Fine sediment was subjected to a near-total decomposition with a four-acid mixture and trace elements were analyzed by inductively coupled plasma mass spectroscopy. Elemental data (excluding mercury) was deemed acceptable if recovery of each element was \pm 15 percent at five times the lower limit of determination. The relative standard deviations of a sample analyzed in triplicate by this method on a similar matrix were 7 percent or less for target elements (Takesue, 2019). Total mercury $\left(\mathrm{Hg}_{\mathrm{T}}\right)$ was measured by cold vapor atomic absorption spectrometry, which has a reporting range from 1 to 100,000 parts per billion. Mercury data were deemed acceptable if recovery was \pm 20 percent at five times the lower limit of determination. The $\mathrm{Hg}_{\mathrm{T}}$ relative standard deviation of a sample analyzed in triplicate by this method on a similar matrix was 10 percent (Takesue, 2019).

\section{Sediment Grain Size and Total Organic Carbon Analyses}

Sediment grain-size distributions were determined on organic- and salt-free sediment using a combination of techniques. Particles with diameters greater than 2 millimeters $(\mathrm{mm})$ were separated by dry sieving into quarter phi intervals (size in millimeters $=2^{- \text {phi }}$ ) and weighed by size class. Sandsized particles $(2 \mathrm{~mm}-63 \mu \mathrm{m})$ and fines (less than $63 \mu \mathrm{m})$ were separated by wet sieving and quantified using a laser particle diffraction counter (Beckman Coulter Life Sciences). Grain-size parameters were calculated with in-house statistical software according to the methods of Folk and Ward (1957). Total carbon (TC) and total inorganic carbon (TIC) were determined coulometrically (UIC, Inc.). Total organic carbon (OC) was calculated as the difference between TC and TIC.

\section{Sediment Quality and Caged Mussel Data}

Bulk sediment concentrations of total PAHs were compared to the Washington State Sediment Management Standards (WASMS), which are reported in OC-normalized units (Toxic Cleanup Program, 2013). Fine-sediment contents of potentially toxic elements were compared to nationally recognized sediment quality guidelines for marine and estuarine sediment (Long and others, 1995). The effects rangelow (ERL) is a minimal-effects level below which adverse biological effects would be rarely observed in demersal fish and invertebrates. The effects range-median (ERM) is the value above which adverse biological effects would be frequently observed. Sediment with analyte contents between the ERL and ERM fall into a possible effects range in which adverse effects would occasionally occur (Long and others, 1995). The WASMS are intermediate or equal to the ERL and ERM for potentially toxic elements except $\mathrm{Cu}, \mathrm{Pb}$, and $\mathrm{Ag}$, for which they are higher. Concentrations of PAHs, $\mathrm{PCBs}$, and potentially toxic elements in caged mussel tissue were obtained from Lanksbury and others (2017). Comparisons between sediment and mussels were based on compounds measured in both (PAHs) or on a common metric (PCBs).

\section{Results and Discussion}

\section{Sediment Grain-Size Distributions}

The size distribution and sorting of sediment particles provide information about hydrodynamic energy and sediment reworking at sites of deposition. The fine sediment fraction is an important parameter for contaminant studies because it is associated with adsorbed compounds and compounds bound to organic matter. Mussel biomonitoring sites were characterized by wide ranges of grain-size distributions, fine-sediment winnowing, and OC contents (fig. 2, table 1). The two bays, Liberty Bay and Samish Bay, had the largest percentages of fine sediment, more than 50 percent (fig. 2), and the highest OC contents (excluding Chimacum Creek, which had an elevated OC value from leaf detritus), indicating they were depositional environments where contaminants would be expected to accumulate in sediment and biota. Although Illahee Park and 

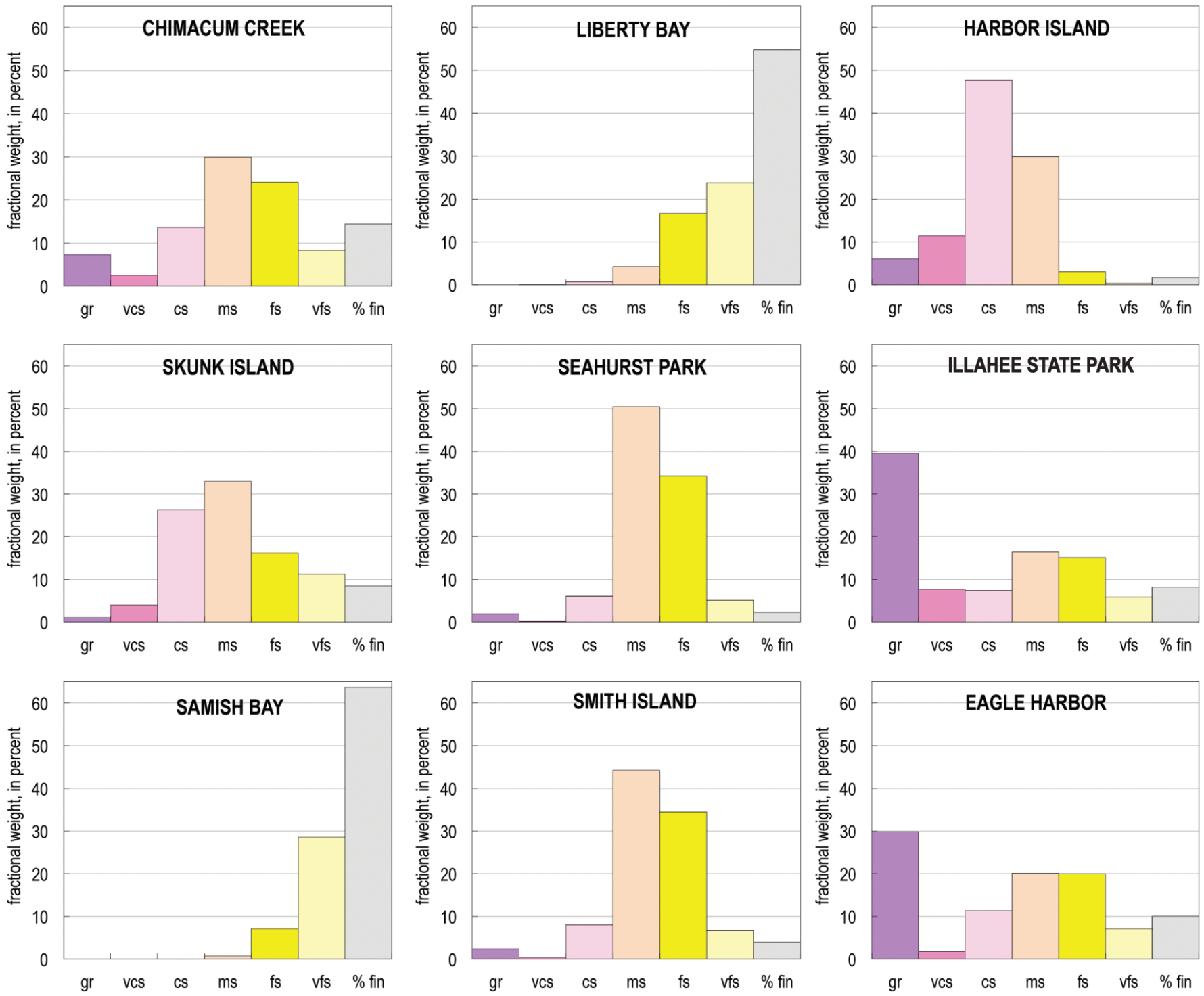

Figure 2. Bar graphs showing sediment grain-size distributions as fractional weights for grain-size classes, Puget Sound, Washington. Grain-size classes are defined as: gr, gravel (2-4 millimeters [mm]); vcs, very coarse sand (1-2 mm); cs, coarse sand (0.5-1 mm); ms, medium sand (250-500 micrometers $[\mu \mathrm{m}]) ;$ fs, fine sand $(125-250 \mu \mathrm{m}) ; \mathrm{vfs}$, very fine sand (63-125 $\mu \mathrm{m}) ; \%$ fin, fines (less than $63 \mu \mathrm{m})$.

Eagle Harbor had large percentages of gravel (fig. 2), they also had higher than average fine fractions and, in the case of Eagle Harbor, an intermediate OC content (table 1), making them sites where contaminants could accumulate to measurable levels in sediment and biota. Sediment size fractions were more evenly distributed at Skunk Island and Chimacum Creek (fig. 2), making them likely sites for contaminant accumulation. There was a very low fraction of fine sediment at Smith Cove, Harbor Island, and Seahurst Park (fig. 2, table 1).

\section{PAH Concentrations in Ambient Fine Sediment}

Total sediment PAH concentrations ranged from 15,200 $\mathrm{ng} / \mathrm{g} \mathrm{OC}$ at Illahee State Park to $125,500 \mathrm{ng} / \mathrm{g}$ OC at Liberty Bay (table 2). This was within the reported concentration range for 40 Puget Sound nearshore sediment sites sampled the following summer, when the sum of 43 PAHs ranged from 7,280 to 989,930 ng/g OC (Black and others, 2018). Although Samish Bay was a muddy depositional environment like Liberty Bay, its total PAH concentration was seven times lower, reflecting differences in new PAH inputs and (or) existing PAH reservoirs. PAH concentrations were highest at the central Puget Sound sites of Liberty Bay, Smith Island, and Eagle Harbor (fig. 3), which had a range of sediment and hydrodynamic characteristics (fig. 2). Eagle Harbor and Illahee State Park had similar grain-size distributions, but total PAH concentrations were six times higher at Eagle Harbor, reflecting differences in new PAH inputs and (or) existing PAH reservoirs. All sites had total PAH concentrations well below the WASMS limit of 1,330,000 ng/g OC (Toxic Cleanup Program, 2013). 
Table 1. Names, abbreviations, sample types, collection dates, coordinates, and sediment characteristics of ten study sites in Puget Sound, Washington, sampled for this study.

[Sediment from Chuckanut Bay was compared to mussels caged at Clark's Point, 850 meters south. There was no mussel cage at Samish Bay. Sites are ordered from north to south. D50, median sediment grain-size diameter; mm, millimeters; fines, weight percent of fine sediment with particle diameters less than 63 micrometers; OC, total organic carbon content; \%, percent; S, sediment; M, mussels]

\begin{tabular}{|c|c|c|c|c|c|c|c|c|}
\hline Site name & Site symbol & Sample type & Date & Latitude & Longitude & $\mathrm{D} 50$ (mm) & Fines $(\%)$ & $\mathrm{OC}(\%)$ \\
\hline Chukanut Bay & $\mathrm{CHU}$ & $\mathrm{S}, \mathrm{M}$ & $9 / 15 / 15$ & 48.6980 & -122.5044 & 0.150 & 15.5 & 0.65 \\
\hline Samish Bay & SAM & S & $2 / 6 / 16$ & 48.6001 & -122.4255 & 0.048 & 63.7 & 1.02 \\
\hline Skunk Island & SKU & $\mathrm{S}, \mathrm{M}$ & $2 / 5 / 16$ & 48.0264 & -122.7503 & 0.355 & 8.4 & 0.58 \\
\hline Liberty Bay & LIB & $\mathrm{S}, \mathrm{M}$ & $2 / 5 / 16$ & 47.7375 & -122.6507 & 0.052 & 54.8 & 1.55 \\
\hline Eagle Harbor & EAG & $\mathrm{S}, \mathrm{M}$ & $2 / 7 / 16$ & 47.6189 & -122.5275 & 0.378 & 10.0 & 0.44 \\
\hline Illahee State Park & ILA & $\mathrm{S}, \mathrm{M}$ & $2 / 7 / 16$ & 47.6032 & -122.5976 & 0.729 & 8.2 & 0.90 \\
\hline Harbor Island & HAR & $\mathrm{S}, \mathrm{M}$ & $2 / 6 / 16$ & 47.5879 & -122.3500 & 0.599 & 1.7 & 0.10 \\
\hline Seahurst Park & SEA & $\mathrm{S}, \mathrm{M}$ & $2 / 9 / 16$ & 47.4632 & -122.3691 & 0.273 & 2.2 & 0.13 \\
\hline
\end{tabular}

${ }^{1}$ Leaf detritus contributed to the anomalously high $\mathrm{OC}$ value at this site.

Table 2. Concentrations of polycyclic aromatic hydrocarbons (PAH) in ambient sediment in units of nanograms per gram of organic carbon (ng/g OC), Puget Sound, Washington.

[Low molecular weight PAHs include naphthalene through phenanthrene; high molecular weight PAHs include pyrene through benzo(g,h,i)perylene. Values are rounded to three significant figures. Values less than three times the blank are in parentheses]

\begin{tabular}{llrrrrrrrr}
\hline \multicolumn{1}{c}{ Abbr. } & \multicolumn{1}{c}{ PAH } & Blank & $\begin{array}{c}\text { Samish } \\
\text { Bay }\end{array}$ & $\begin{array}{c}\text { Chimacum } \\
\text { Creek }\end{array}$ & $\begin{array}{r}\text { Skunk } \\
\text { Island }\end{array}$ & $\begin{array}{r}\text { Liberty } \\
\text { Bay }\end{array}$ & $\begin{array}{r}\text { Smith } \\
\text { Cove }\end{array}$ & $\begin{array}{c}\text { Eagle } \\
\text { Harbor }\end{array}$ & $\begin{array}{c}\text { Illahee } \\
\text { State Park }\end{array}$ \\
\hline NAP & Naphthalene & 0 & 0 & 0 & 0 & 0 & 0 & 0 & 0 \\
C1NPH & 1-methyl naphthalene & 0 & 38 & 65 & 70 & 96 & 148 & 0 & 0 \\
C2NPH & 2-methyl naphthalene & 0 & 19 & 89 & 70 & 138 & 0 & 0 & 0 \\
ACY & Acenaphthylene & 0 & 86 & 585 & 514 & 434 & 1,050 & 1,480 & 90 \\
ACE & Acenaphthene & 147 & $(37)$ & $(129)$ & $(188)$ & 655 & $(409)$ & $(149)$ & 0 \\
FLU & Fluorene & 0 & 59 & 526 & 485 & 1,230 & 1,500 & 570 & 0 \\
ANT & Anthracene & 0 & 483 & 5,540 & 3,330 & 18,000 & 6,810 & 3,020 & 0 \\
PHN & Phenanthrene & 0 & 130 & 1,320 & 1,270 & 2,930 & 4,980 & 3,540 & 0 \\
PYR & Pyrene & 0 & 2,060 & 1,980 & 12,300 & 20,700 & 14,300 & 14,700 & 1,320 \\
FLA & Fluoranthene & 0 & 2,550 & 2,580 & 14,600 & 25,400 & 15,400 & 15,600 & 824 \\
CHR & Chrysene & 222 & 3,530 & $(576)$ & 2,320 & 9,270 & 8,320 & 3,970 & 0 \\
BAA & Benzo[a]anthracene & 4 & 0 & 3,670 & 641 & 5,000 & 7,700 & 619 & 2,430 \\
BBF & Benzo[b]fluoranthene & 0 & 1,060 & 3,880 & 5,970 & 13,100 & 11,300 & 16,900 & 1,290 \\
BKF & Benzo[k]fluoranthene & 0 & 859 & 2,360 & 4,110 & 7,990 & 7,760 & 5,100 & 1,430 \\
BEP & Benzo[e]pyrene & 0 & 2,630 & 4,310 & 5,080 & 3,280 & 15,500 & 8,200 & 3,870 \\
IDP & Indeno[1,2,3-c,d]pyrene & 0 & 1,030 & 4,340 & 3,650 & 8,310 & 10,900 & 8,330 & 1,570 \\
DBA & Dibenzo[a,h]anthracene & 0 & 1,750 & 962 & 2,560 & 1,640 & 13,700 & 6,240 & 1,880 \\
BZP & Benzo[g,h,i]perylene & 0 & 1,330 & 3,060 & 2,170 & 7,440 & 1,690 & 4,060 & 469 \\
\hline & Total PAHs (EPAHs) & 372 & 17,600 & 36,000 & 59,300 & 125,500 & 121,500 & 92,400 & 15,200 \\
& Low molecular weight & 147 & 853 & 8,250 & 5,930 & 23,500 & 14,900 & 8,760 & 90 \\
& High molecular weight & 225 & 16,800 & 27,700 & 53,300 & 102,000 & 106,600 & 83,600 & 15,100 \\
\hline
\end{tabular}




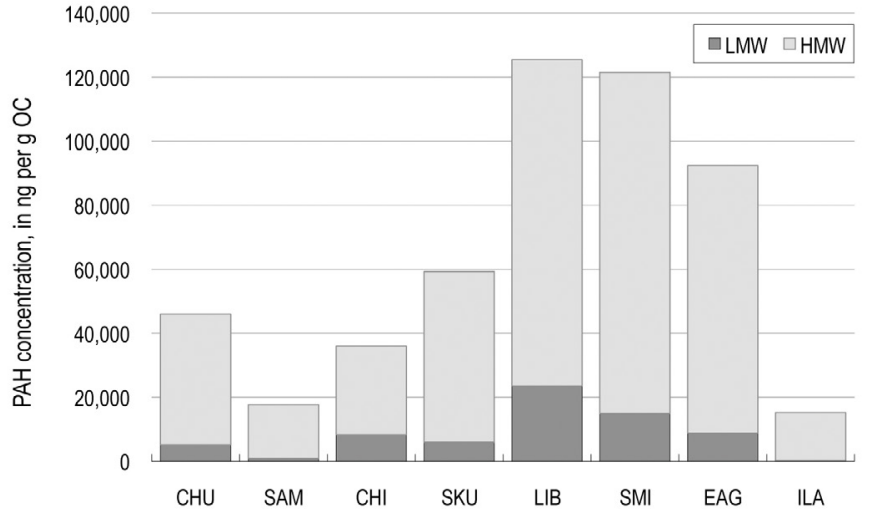

Figure 3. Stacked bar graph showing concentrations (in nanograms per gram of organic carbon, $\mathrm{ng} / \mathrm{g} \mathrm{OC}$ ) of high and low molecular weight (HMW and LMW) polycyclic aromatic hydrocarbons (PAHs) in ambient sediment ( $0-2$ centimeter layer), Puget Sound, Washington. Cumulative column heights show total PAH concentrations. CHU, Chuckanut Bay; SAM, Samish Bay; CHI, Chimacum Creek; SKU, Skunk Island; LIB, Liberty Bay; SMI, Smith Cove; EAG, Eagle Harbor; ILA, Illahee State Park.

\section{Comparisons of PAHs and Diagnostic Ratios in Ambient Fine Sediment and Caged Mussels}

PAH concentrations in caged mussels can only be qualitatively compared to those in ambient sediment because sediment data were OC-normalized. Assemblages of individual PAHs are shown in ambient sediment and mussel tissue in figure 4 . The two were highly correlated at Liberty Bay (the Pearson correlation coefficient, $r$, is 0.80 and the $\mathrm{p}$-value, $p$, is 0.01 ) and Eagle Harbor $(r=0.67, p=0.01)$, and moderately correlated at Smith Cove $(r=0.58, p=0.02)$. These were also the sites with the highest sedimentary PAH levels among the eight characterized for this study. Strong correlations between mussel and sediment PAH assemblages could indicate that sediments play an important role in PAH uptake by mussels at these sites. Correlations between sediment and caged mussel PAH assemblages were not significant at sites with lower sedimentary PAH levels, evidenced by low or negative correlation coefficients and (or) large p-values (fig. 4).

Of the ten high molecular weight PAHs found to co-occur in sediment and caged mussels, only 3-6 were detected in mussels with individual PAH concentrations less than $50 \mathrm{ng} / \mathrm{g}$ dry weight (DW) (fig. 4). In addition, the three highest molecular weight PAHs (IDP, BZP, and DBA) were disproportionately low in mussels with individual PAH levels greater than $50 \mathrm{ng} / \mathrm{g}$ DW (Smith Cove, Eagle Harbor, and Liberty Bay; fig. 4). No consistent relationship was found between total PAH concentrations ( $\mathrm{PAH}$ ) in sediment and mussels at the three sites with highest $\Sigma$ PAHs: sedimentary $\Sigma$ PAHs were similar at Liberty Bay $(125,500 \mathrm{ng} / \mathrm{g}$ DW) and Smith Cove (121,457 ng/g DW), yet mussel tissue 5 PAHs were an order of magnitude lower at Liberty Bay than Smith Cove; Eagle Harbor had lower $\Sigma$ PAHs in sediment $(92,386 \mathrm{ng} / \mathrm{g}$ DW) than Liberty Bay and higher $\mathrm{PAH}$ in mussel tissue than
Liberty Bay (fig. 4). These findings demonstrate the complexity of factors influencing contaminant levels in biota and nearshore sediment and suggest that other sources besides sediment contribute to mussel body burdens of PAHs at these locations.

Diagnostic PAH ratios at Chimacum Creek, Skunk Island, Liberty Bay, Smith Cove, and Eagle Harbor were indicative of PAHs sourced from biomass and (or) coal burning (fig. 5). PAH ratios in sediment from Chuckanut Bay were diagnostic of PAHs sourced from petroleum combustion, consistent with the site's proximity to the Burlington Northern Santa Fe rail line (fig. 5). Diagnostic ratios were mixed at Samish Bay and Illahee State Park, indicating that PAHs were sourced from the incomplete combustion of biomass/coal or petroleum (Samish Bay) and the incomplete combustion of biomass/coal combustion or liquid petroleum (Illahee State Park) (fig. 5). The low to high molecular weight (LMW/HMW) ratio, which distinguishes petrogenic from combustion-derived PAHs (Tobiszewski and Namiesnik, 2012), was indicative of combustion-derived PAHs at Illahee State Park, so the petrogenic fluoranthene to pyrene ratio was disregarded. The LMW/HMW ratio did not distinguish between combusted petroleum versus biomass/coal as PAH sources in Samish Bay sediment. The four individual PAHs used in diagnostic ratios were detected in caged mussels at only two sites, Eagle Harbor and Smith Cove, and were indicative of PAHs sourced from the incomplete combustion of biomass/coal, similar to those in ambient sediment (fig. 5).

\section{PCB Contents of Ambient Fine Sediment}

Total PCB concentrations in nearshore fine sediment ranged from $0.427 \mathrm{ng} / \mathrm{g}$ at Samish Bay to $32.3 \mathrm{ng} / \mathrm{g}$ at Smith Cove (table 3). The other industrial embayment near SeattleHarbor Island - also had elevated PCBs $(23.6 \mathrm{ng} / \mathrm{g})$, and the concentrations within other embayments-Eagle Harbor and Skunk Island - were intermediate $(7.78$ and $5.79 \mathrm{ng} / \mathrm{g}$, respectively). There is no previous PCB data for Puget Sound sediment at this shallow nearshore elevation ( 0 feet MLLW). Concentrations in approximately 40 nearshore sediment samples collected from -6 feet MLLW and sieved to less than $2 \mathrm{~mm}$ (versus less than $63 \mu \mathrm{m}$ in this study) ranged from 0.016 to $359 \mathrm{ng} / \mathrm{g}$ (Black and others, 2018). Concentrations of PCBs in unsieved deep-marine sediment samples collected from 2003-2013 in Puget Sound span a wide range of concentrations likely owing to spatial, temporal, grain size, and organic carbon differences (https://ecology.wa.gov/Research-Data/ Monitoring-assessment/Puget-Sound-and-marine-monitoring). Similarly, the results from this study cannot be compared directly to the WASMS of 12 milligrams of total PCBs per kilogram of OC (Toxic Cleanup Program, 2013), because the sample was sieved and the OC content was determined on the bulk sample. In addition, the WASMS applies to Aroclor-based results; currently, there is no congener-based standard. A rough calculation using the median sedimentary OC content of 0.65 percent among the ten study sites (table 1) indicates that total 


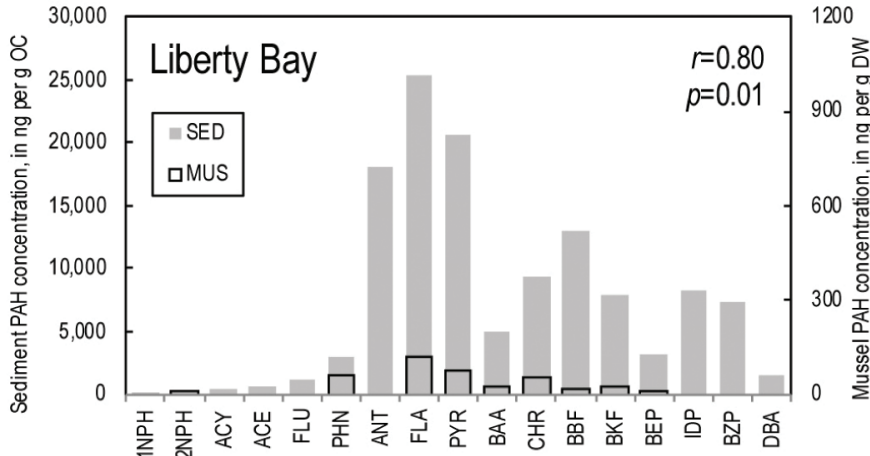

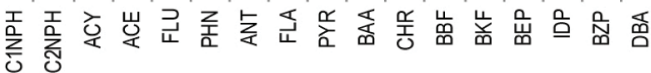

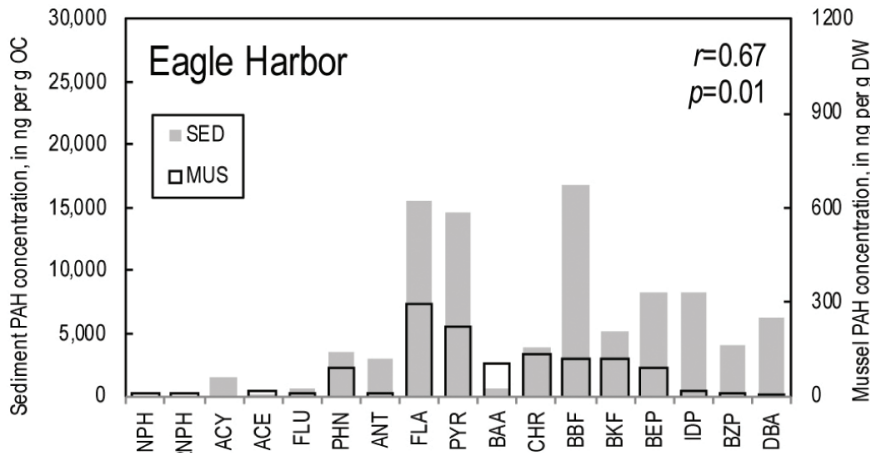

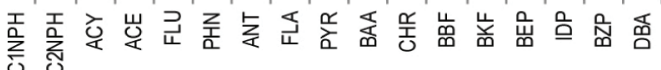

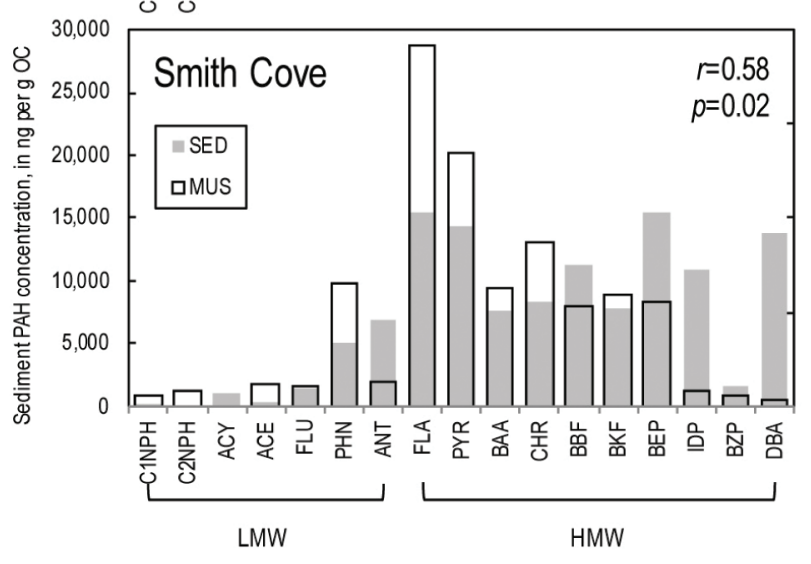

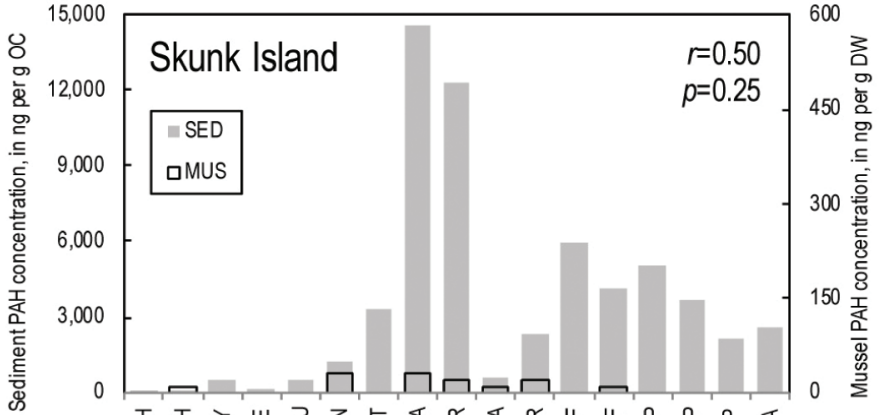

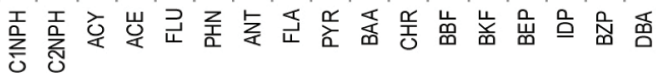

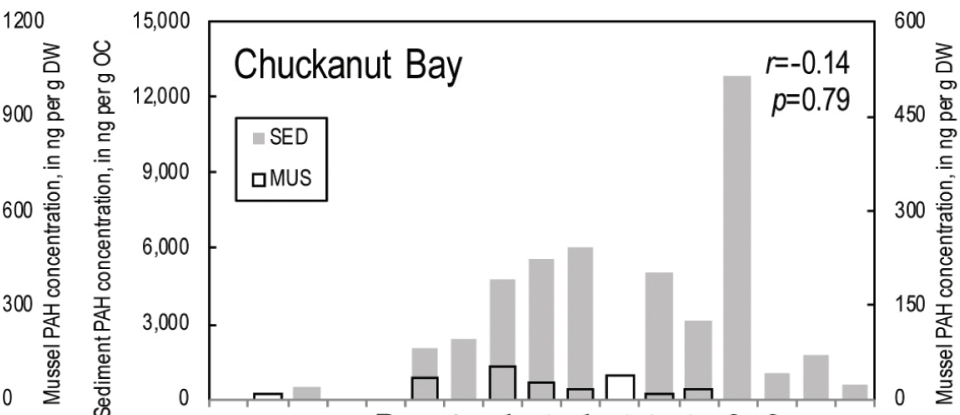

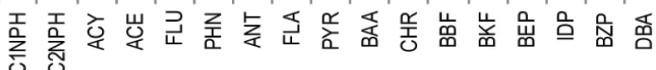
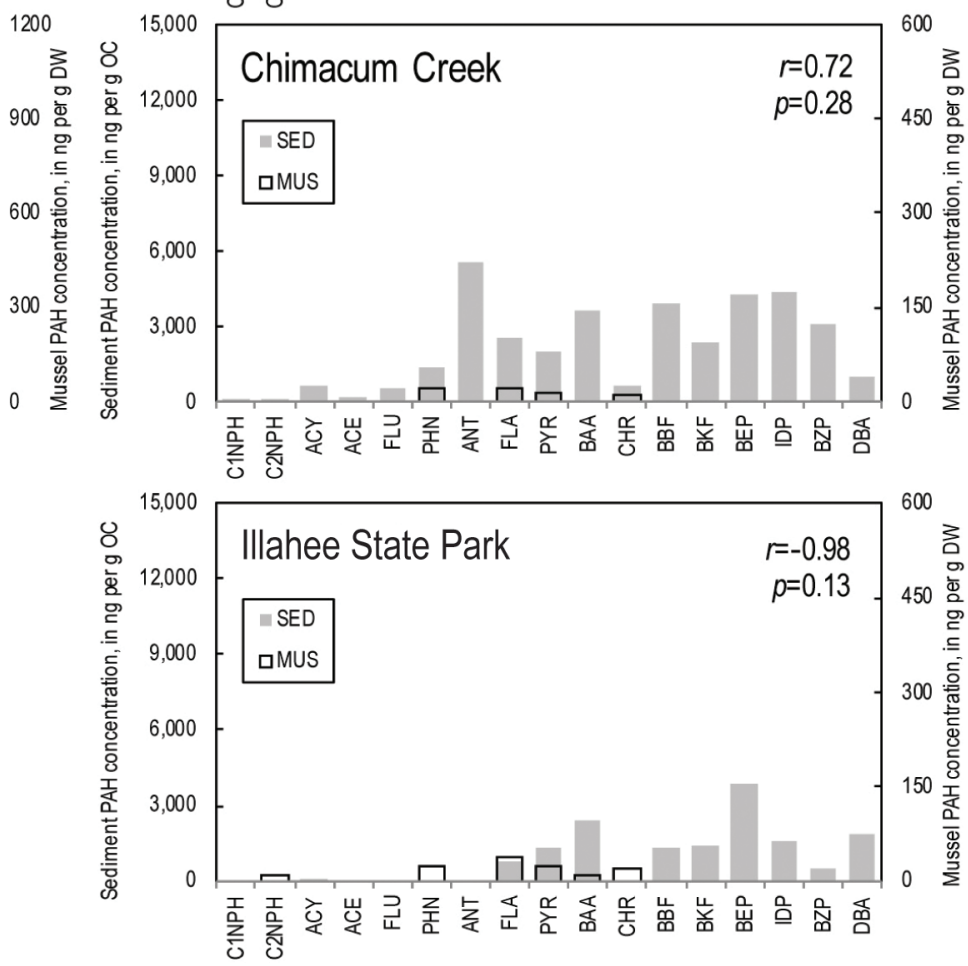

Figure 4. Bar graphs of individual polycyclic aromatic hydrocarbon (PAH) concentrations in sediment (SED) and caged mussels (MUS) at each study site, Puget Sound, Washington. PAHs are ordered by increasing molecular weight; low molecular weight (LMW) and high molecular weight (HMW) fractions are indicated at the bottom of the left column. The Pearson linear correlation coefficient, $r$, for each sediment-mussel pair is shown in the upper right corner with the correlation $p$-value $(p)$. $\mathrm{ng}$, nanograms; $\mathrm{g}$, grams; $\mathrm{OC}$, organic carbon; DW, dry weight. See table 2 for PAH abbreviations. Mussel data are from Lanksbury and others (2017). 


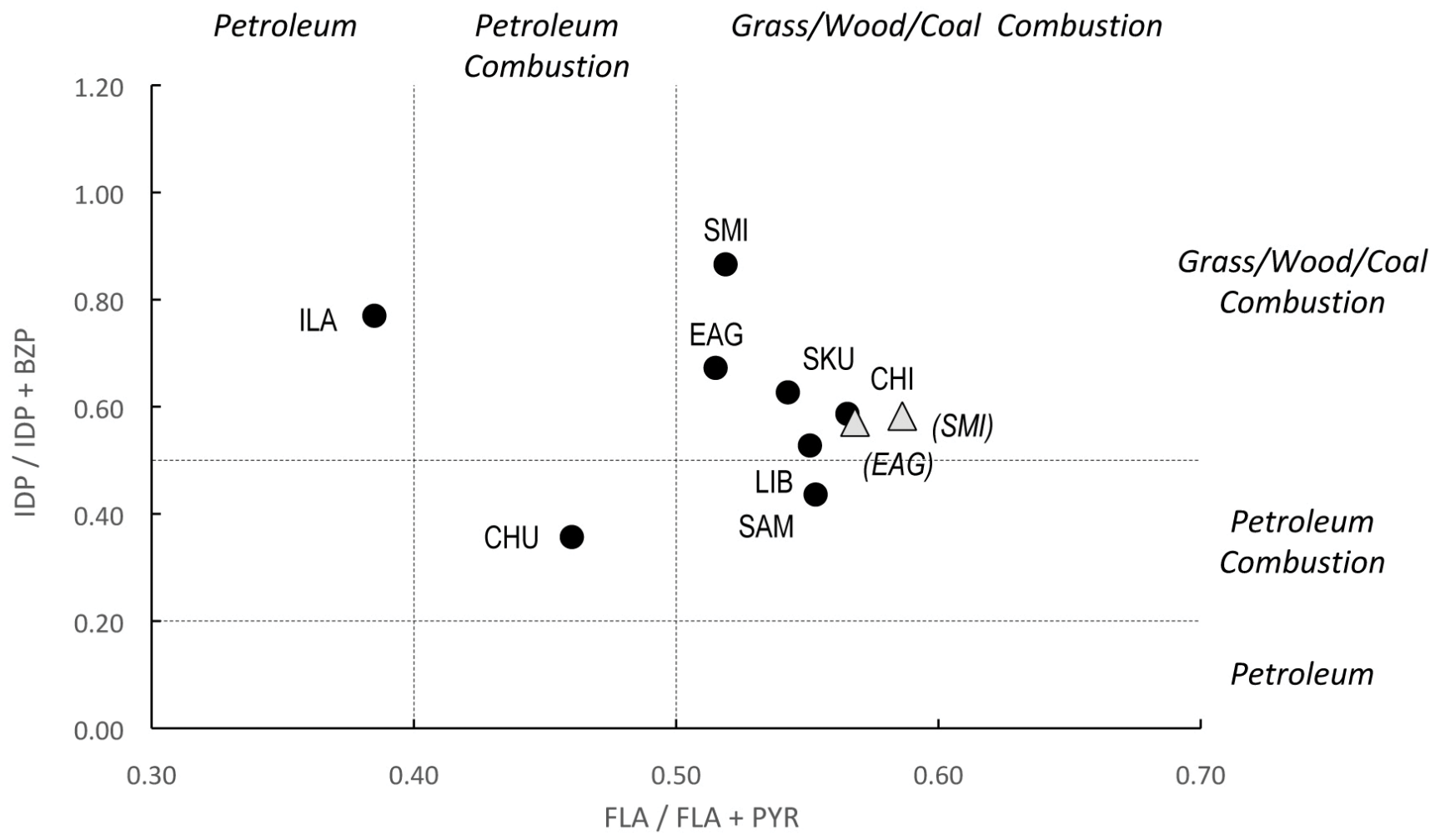

Figure 5. Bivariate plot of diagnostic polycyclic aromatic hydrocarbon (PAH) ratios in ambient sediment (circles) and caged mussels (triangles), Puget Sound, Washington. PAH abbreviations are: IDP, indeno[1,2,3-c,d]pyrene; BZP, benzo(g,h,i)perylene; FLA, fluoranthene; and PYR, pyrene. Study site abbreviations are: SAM, Samish Bay; CHI, Chimacum Creek; SKU, Skunk Island; LIB, Liberty Bay; SMI, Smith Cove; EAG, Eagle Harbor; ILA, Illahee State Park. Labels for mussel sites are shown in parentheses. Diagnostic PAH values are from Tobiszewski and Namiesnik (2012); mussel data are from Lanksbury and others (2017).

PCBs were several orders of magnitude below the WASMS. For comparison purposes, median PCB concentrations were $5.49 \mathrm{ng} / \mathrm{g}$ in fine bed sediment in the nonestuarine part of the Duwamish River, which enters Puget Sound in Seattle near Harbor Island (Conn and others, 2015). PCBs preferentially sorb to fine sediment: concentrations on Duwamish River fine bed sediment were 1.8 to 4.5 times higher than in corresponding bulk bed sediment samples sieved to less than $2 \mathrm{~mm}$ (Conn and others, 2015).

The contribution of individual congeners to the total concentration (the "fingerprint") was similar between sites (fig. 6). For example, penta- and hexa-chlorobiphenyls contributed 50 to 66 percent of the total PCB concentration. In exception, these two groups contributed 80 percent of the total PCB concentration at Skunk Island, with the pentachlorinated congeners alone contributing 50 percent.

\section{Comparisons of PCBs in Ambient Fine Sediment and Caged Mussels}

In general, concentrations of PCBs were higher in samples of sediment and mussel tissue collected in embayments compared to open shoreline locations (fig. 7). The wide range of $\mathrm{PCB}$ concentrations in mussel tissue indicates bioaccumulation rather than metabolism of PCBs by mussels during the three-month deployment (Lanksbury and others, 2017). There was no overall quantitative relation between mussel tissue and colocated sediment concentrations, but two industrial embayments with the highest PCB concentrations in caged mussels were among those with the highest PCB concentrations in sediment (for example, Smith Cove and Eagle Harbor; note that mussels were not recovered from Harbor Island). Ratios of PCB concentrations in mussel tissue to sediment ranged from 3:1 (Skunk Island, mussels $=16.2$ micrograms per kilogram $[\mu \mathrm{g} / \mathrm{kg}] \mathrm{DW}$; sediment $=5.3 \mu \mathrm{g} / \mathrm{kg}$ DW) to 57:1 (Illahee State Park, mussels $=46.0 \mu \mathrm{g} / \mathrm{kg} \mathrm{DW}$; sediment $=0.8 \mu \mathrm{g} / \mathrm{kg}$ DW). To directly compare sediment and tissue concentrations, sediment results in figure 7 are presented as WDFW equivalents (the sum of 17 congeners and any co-eluting congeners multiplied by two). The WDFW equivalent concentration was, on average, 10 percent lower (ranging from 3.6 to 27 percent lower) than the total PCB concentration determined as the sum of 209 congeners (table 3 ).

PCBs in oyster tissue and colocated sediment in two Oregon estuaries - Netarts Bay and Coos Bay - were within the range of concentrations measured in this study (7.64 and $5.94 \mathrm{ng} / \mathrm{g} \mathrm{DW}$ in oyster tissue and 1.59 and $4.1 \mathrm{ng} / \mathrm{g}$ DW in sediment sieved to less than $2 \mathrm{~mm}$, respectively) (Granek and others, 2016). 


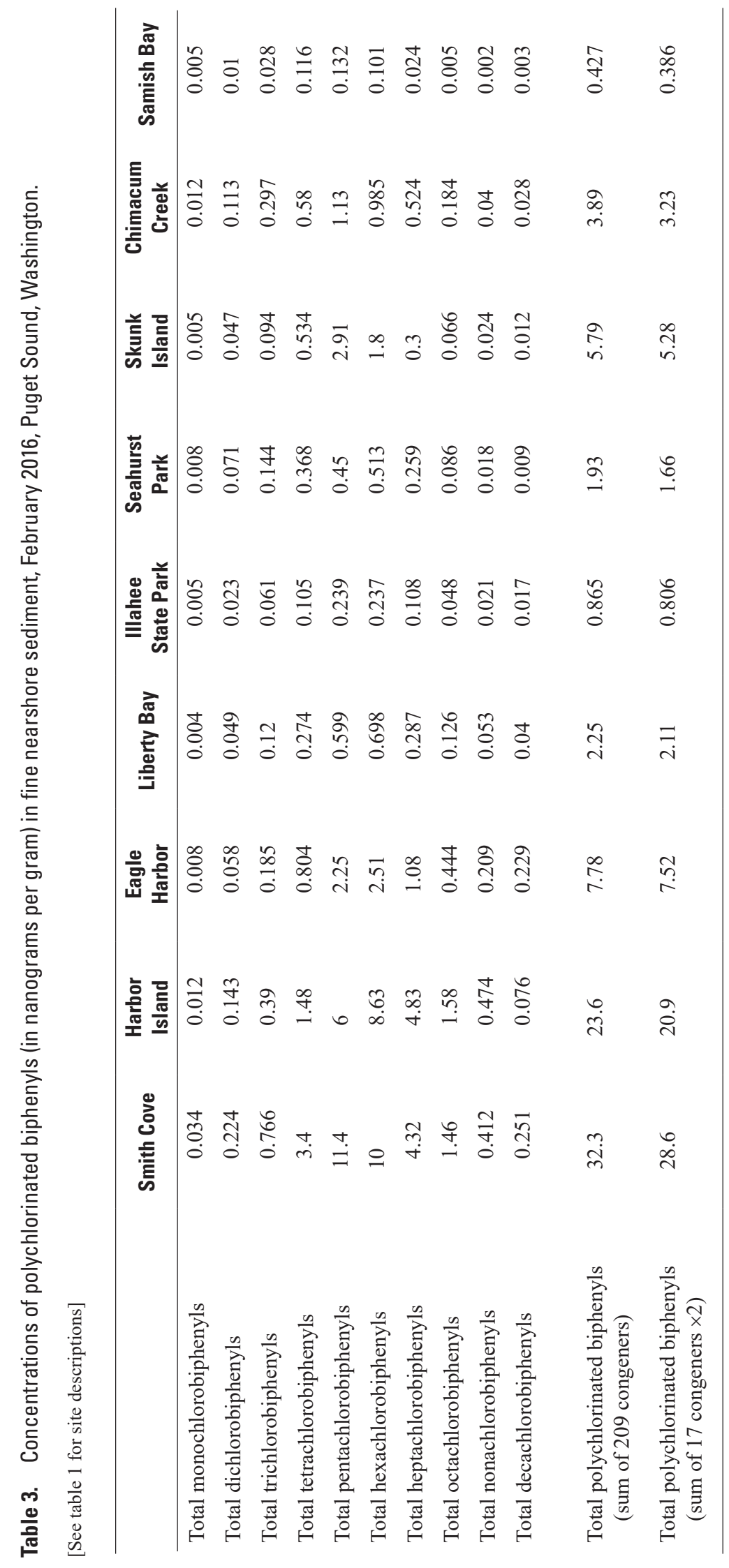




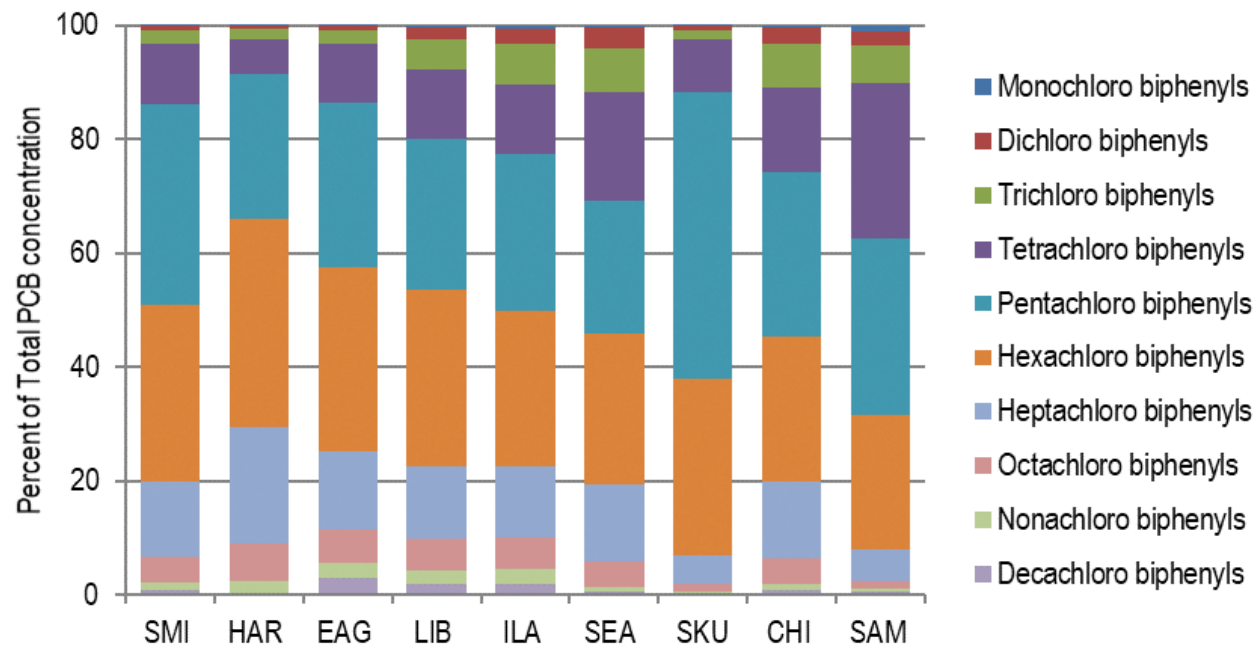

Figure 6. Plot showing the contribution (in percent) of congeners (grouped by number of chlorine atoms) to the total polychlorinated biphenyl (PCB) concentration in fine nearshore sediment, February 2016, Puget Sound, Washington. Study site abbreviations are: SMI, Smith Cove; HAR, Harbor Island; EAG, Eagle Harbor; LIB, Liberty Bay; ILA, Illahee State Park; SEA, Seahurst Park; SKU, Skunk Island; CHI, Chimacum Creek; SAM, Samish Bay.

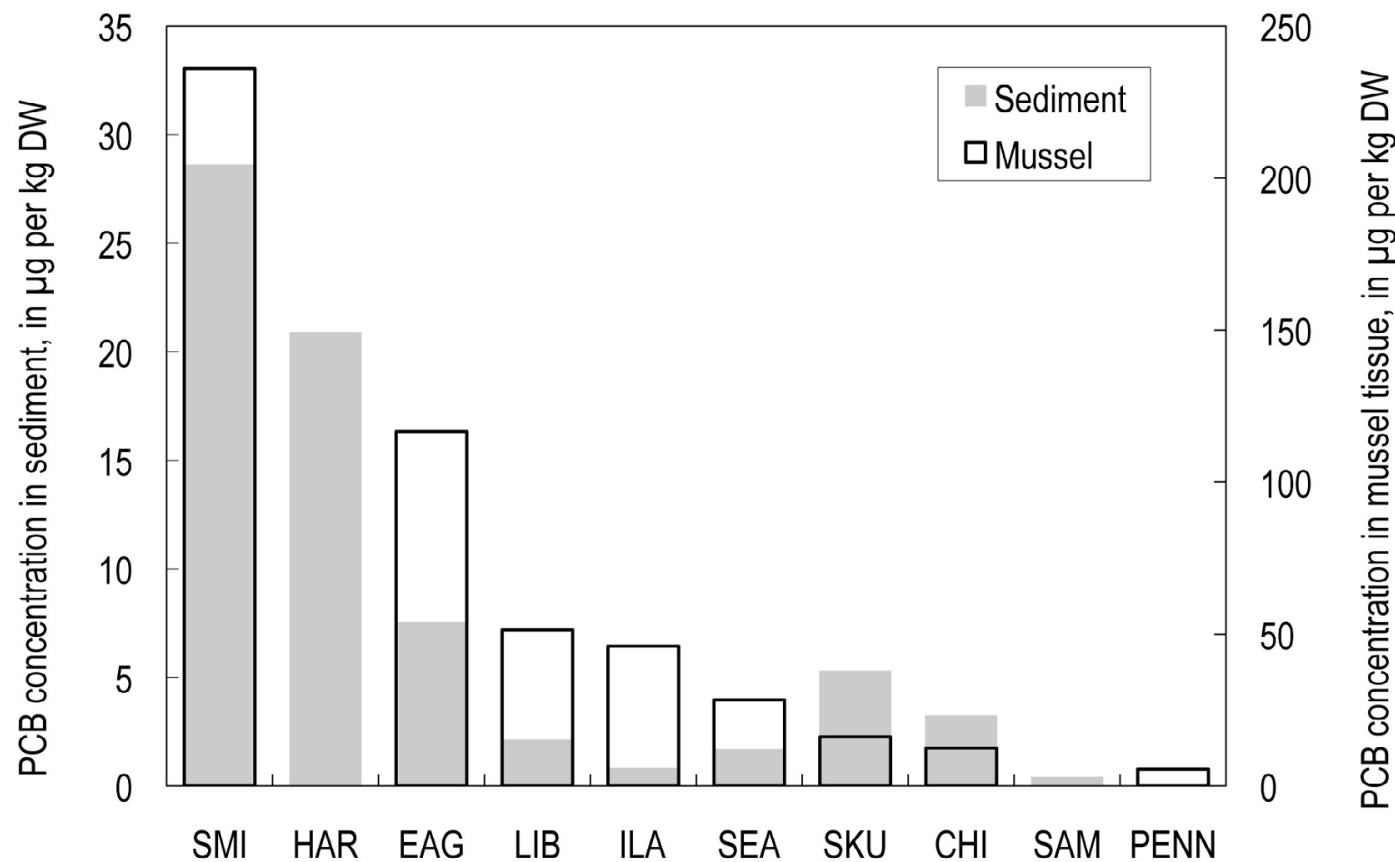
(E)
(E)
(E)
(E)
(O)
(O)
(O)
(O)
(E)
(R)

Figure 7. Bar graph showing polychlorinated biphenyl (PCB) concentrations (in micrograms [ $\mu \mathrm{g}]$ per kilogram [kg] of dry weight [DW]) in nearshore fine sediment and caged mussels in Puget Sound, Washington, embayments (E) and open shoreline sites (O) as Washington Department of Fish and Wildlifeequivalent values (the sum of 17 congeners and their co-eluting congeners multiplied by 2). There were no caged mussels at Samish Bay or recovered from Harbor Island. PENN represents the mussel reference (R) PCB concentration; sediment was not analyzed there. Mussel data are from Lanksbury and others (2017). Study site abbreviations are: SMI, Smith Cove; HAR, Harbor Island; EAG, Eagle Harbor; LIB, Liberty Bay; ILA, Illahee State Park; SEA, Seahurst Park; SKU, Skunk Island; CHI, Chimacum Creek; SAM, Samish Bay. 


\section{Arsenic and Potentially Toxic Metals in Ambient Fine Sediment}

Fine sediment contents of $\mathrm{Cd}$ and $\mathrm{Pb}$ were below the ERL at all sites, and contents of $\mathrm{As}, \mathrm{Cu}, \mathrm{Hg}_{\mathrm{T}}$, and $\mathrm{Zn}$ were between the ERL and ERM and below the WASMS at one to three caged mussel sites (fig. 8, table 4). The highest levels occurred at Eagle Harbor (As), Harbor Island (Cd, Cu, Pb, Zn), and Smith Cove $\left(\mathrm{Hg}_{\mathrm{T}}\right)$ (fig. 8). At no sites did potentially toxic elements exceed WASMS or ERM levels (table 4). Elevated $\mathrm{As}, \mathrm{Cd}$, and $\mathrm{Cu}$ in fine sediment at Chimacum Creek, which also had unusually high $\mathrm{OC}$, likely reflect enrichment of these elements in reducing sediments. The elevated $\mathrm{Hg}_{\mathrm{T}}$ in fine sediment at Chuckanut Bay relative to nearby Samish Bay could reflect legacy sedimentary $\mathrm{Hg}$ enrichment from a chloralkali plant outfall in Bellingham Bay that operated until 1979 (Crecelius and others, 1975).

\section{Arsenic and Potentially Toxic Metals in Ambient Fine Sediment and Caged Mussels}

Contents of $\mathrm{As}, \mathrm{Cd}, \mathrm{Cu}, \mathrm{Hg}_{\mathrm{T}}$, and $\mathrm{Zn}$ were less variable in caged mussels than in ambient fine sediment (fig. 9), a pattern that is consistent with the bioregulation of metals known to occur in bivalves (Luoma, 1989). In contrast, mussel $\mathrm{Pb}$ contents, and possibly $\mathrm{Cu}$ to a lesser extent, generally increased as sedimentary metal contents increased across Puget Sound sites (fig. 9). Sediment and mussel contents of $\mathrm{Cu}, \mathrm{Hg}_{\mathrm{T}}, \mathrm{Zn}$, and all but one site for $\mathrm{Pb}$ were higher in embayments than at open shoreline sites (fig. 9). No mussels were recovered from Harbor Island - the site with the highest ambient sediment metal contents in February 2016. Potentially toxic element contents in fine sediment at Chukanut Bay collected in September 2015 were higher than in nearby Samish Bay collected in February 2016 (table 4), an indication that winter 2015-2016 stormwater runoff was not the only source of these elements. Fine sediment contents of As, Zn, and to a lesser extent $\mathrm{Hg}_{\mathrm{T}}$, were intermediate at Chukanut Bay compared to the sites characterized for this study (fig. 9), suggesting that nonstormwater inputs of these elements could be important.

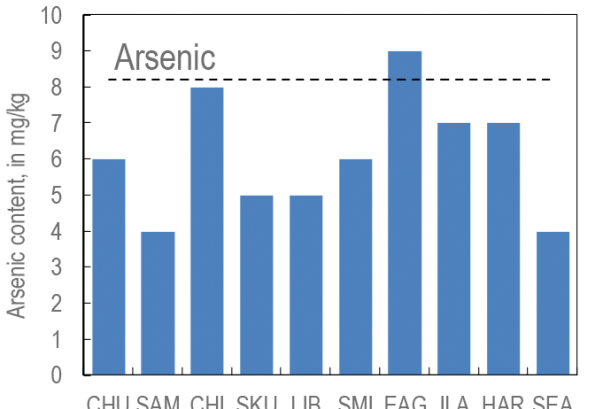

CHU SAM CHI SKU LIB SMI EAG ILA HAR SEA

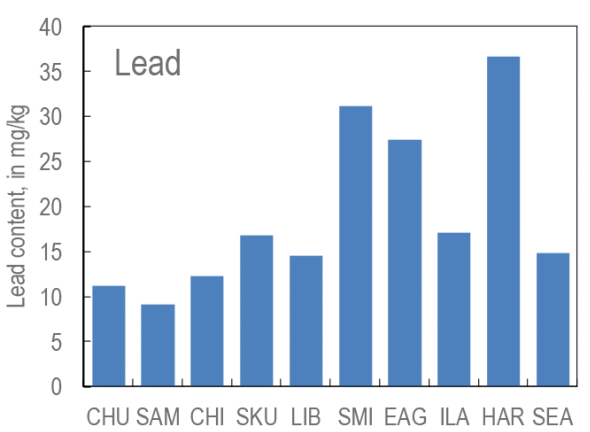

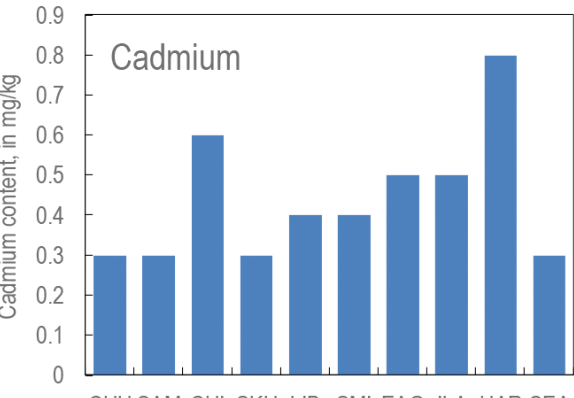

CHU SAM CHI SKU LIB SMI EAG ILA HAR SEA

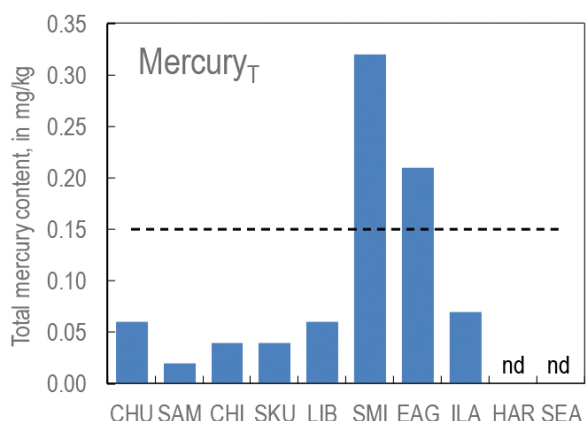

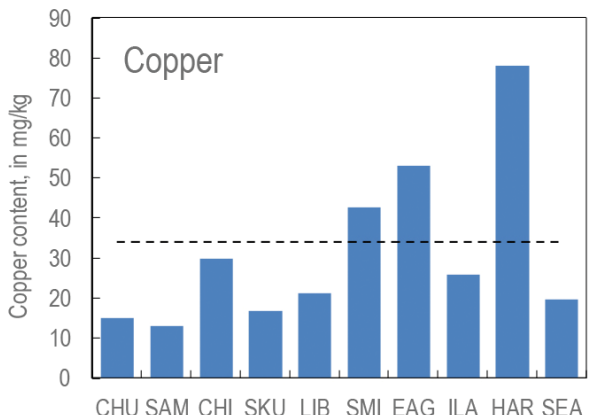

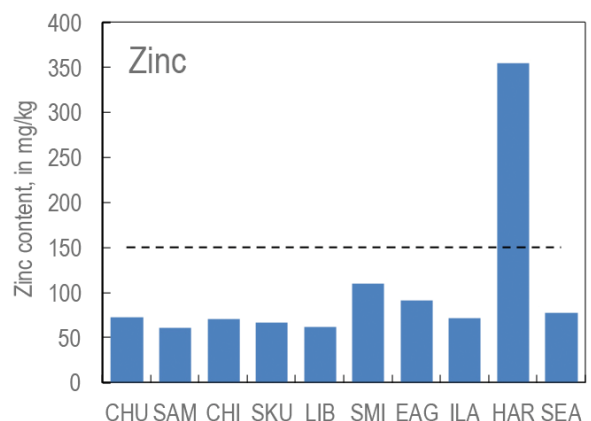

Figure 8. Bar graphs showing arsenic and potentially toxic metal contents (in milligrams per kilogram [mg/kg]) in fine sediment at all study sites, Puget Sound, Washington. Dashed line shows the effects range-low (ERL); graphs with no dashed line show metals that were below the ERL. Subscript T stands for total. Study site abbreviations are: CHU, Chukanut Bay; SAM, Samish Bay; CHI, Chimacum Creek; SKU, Skunk Island; LIB, Liberty Bay; SMI, Smith Island; EAG, Eagle Harbor; ILA, Illahee State Park; HAR, Harbor Island; SEA, Seahurst Park. nd, not determined. 

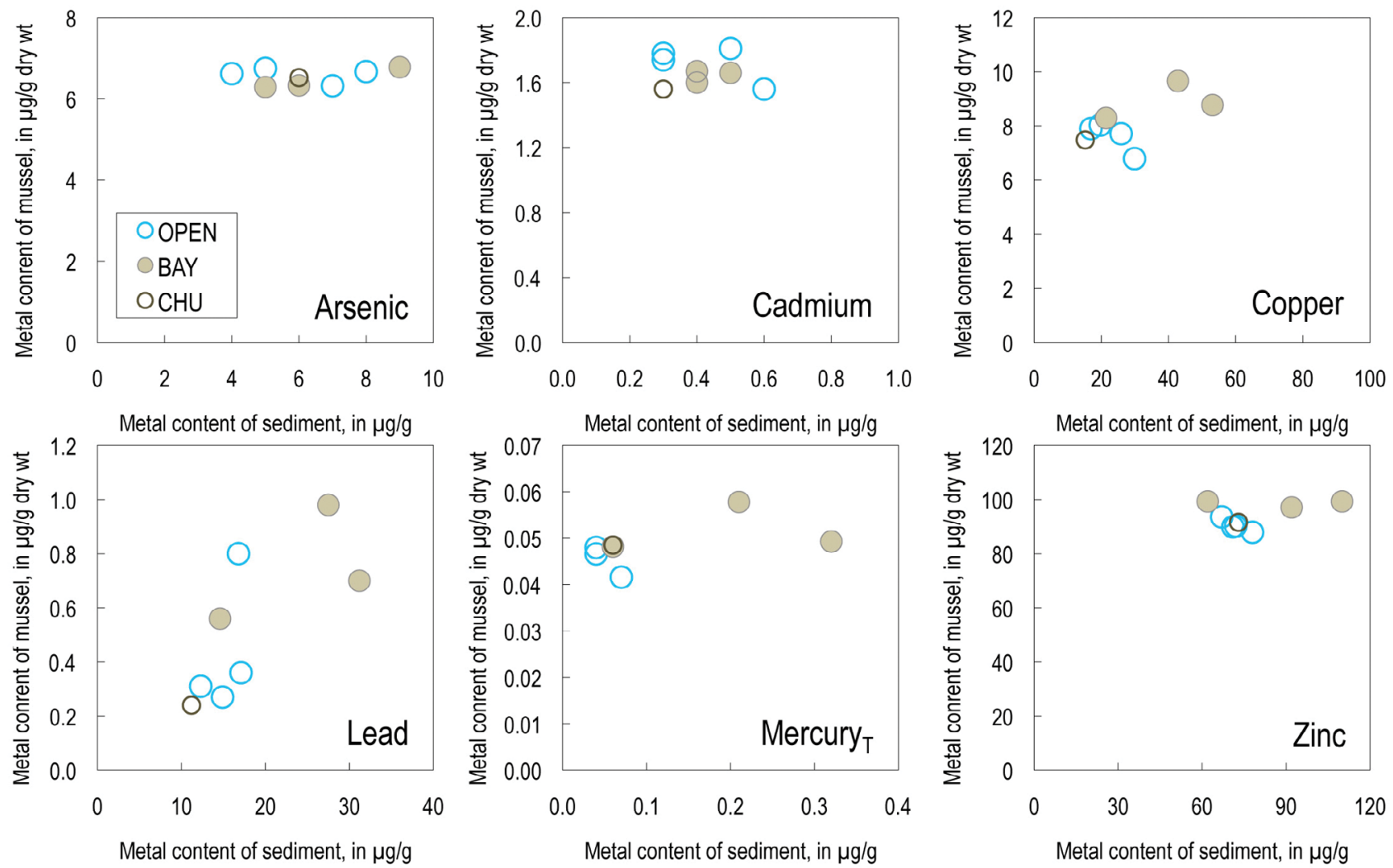

Figure 9. Plots of potentially toxic element concentrations (in micrograms per gram [ $\mu \mathrm{g} / \mathrm{g}]$ of dry weight) in ambient fine sediment versus caged mussels, Puget Sound, Washington. Blue circles show open shoreline sites; brown closed circles show embayment sites. Sediment from Chukanut Bay (CHU, open brown circle) was collected 1 month prior to the fall-winter mussel deployment. Mussel data from Lanksbury and others (2017).

Table 4. Contents of potentially toxic elements in fine sediment at caged mussel sites and Samish Bay, Puget Sound, Washington.

[Data reported in milligrams per kilogram $(\mathrm{mg} / \mathrm{kg})$. Values greater than the effects range-low are in bold font. Deployment and recovery of mussel cages are indicated in the last column. ERL, effects range-low; ERM, effects range-median; ins, insufficient material for analysis]

\begin{tabular}{lccccccc}
\hline & Arsenic & Cadmium & Copper & Total mercury & Lead & Zinc & Mussels \\
\hline Chukanut Bay & 6 & 0.3 & 15 & 0.06 & 11.2 & 73 & Yes \\
Chimacum Creek & 8 & 0.6 & 30 & 0.04 & 12.3 & 71 & Yes \\
Skunk Island & 5 & 0.3 & 17 & 0.04 & 16.8 & 67 & Yes \\
Samish Bay & 4 & 0.3 & 13 & 0.02 & 9.2 & 61 & No \\
Liberty Bay & 5 & 0.4 & 21 & 0.06 & 14.6 & 62 & Yes \\
Seahurst Park & 4 & 0.3 & 20 & ins & 14.9 & 78 & Yes \\
Smith Cove & 6 & 0.4 & $\mathbf{4 3}$ & $\mathbf{0 . 3 2}$ & 31.2 & 110 & Yes \\
Harbor Island & 7 & 0.8 & $\mathbf{7 8}$ & ins & 36.7 & $\mathbf{3 5 5}$ & No \\
Illahee State Park & 7 & 0.5 & 26 & 0.07 & 17.1 & 72 & Yes \\
Eagle Harbor & $\mathbf{9}$ & 0.5 & $\mathbf{5 3}$ & $\mathbf{0 . 2 1}$ & 27.5 & 92 & Yes \\
\hline Median & 6 & 0.4 & 26 & 0.06 & 16.8 & 72 & \\
ERL $^{1}$ & 8 & 1.2 & 34 & 0.15 & 46.7 & 150 & \\
WASMS $^{2}$ & 57 & 5.1 & 390 & 0.41 & 450 & 410 & \\
ERM $^{1}$ & 70 & 9.6 & 270 & 0.71 & 218 & 410 & \\
\hline
\end{tabular}

${ }^{1}$ Long and others (1995).

${ }^{2}$ Toxic Cleanup Program (2013). 


\section{Conclusions}

Sedimentary concentrations of polycyclic aromatic hydrocarbons (PAHs), polychlorinated biphenyls (PCBs), arsenic, and potentially toxic metals $\left(\mathrm{Cd}, \mathrm{Cu}, \mathrm{Hg}_{\mathrm{T}}, \mathrm{Pb}, \mathrm{Zn}\right)$ were characterized at nine sites to complement a stormwater study using caged mussels as biomonitors during October 2015-February 2016 in Puget Sound and Samish Bay, in Washington State. This study investigated the role of ambient sediment as a source of contaminants to mussels. In general, PAH, PCB, and metal levels were low in ambient sediment at intertidal mussel biomonitoring sites; nevertheless, contaminants in sediment and mussels were elevated at industrial and urban sites compared to less developed sites. Only Liberty Bay showed a resemblance between sediment and mussel PAH assemblages and diagnostic PAH ratios indicative of coal/biomass combustion sources. Although sediment may have been an important vector for contaminant uptake in mussels in Liberty Bay, this mechanism could not be applied to the rest of the sites based on the available data. There was a general correspondence between sediment and mussel total PCB concentrations, suggesting that sediment is an exposure route of mussels to PCBs in industrial embayments. In contrast, mussels appeared to bioregulate tissue concentrations of As, $\mathrm{Cd}, \mathrm{Hg}_{\mathrm{T}}$, and $\mathrm{Zn}$, making mussels nonlinear biomonitors of these elements. Ambient fine sediment was a potential source of lead to Puget Sound mussels. This study highlights the complex suite of factors affecting contaminant concentrations in mussel tissue (dissolved and particulate-bound uptake, metabolism, and depuration) and in sediment (grain-size distribution, organic carbon content, and resuspension dynamics), which complicate extrapolation from one matrix type to the other.

\section{Acknowledgments}

Funding for this work was provided by the U.S. Geological Survey (USGS) Ecosystems Mission Area and the USGS Coastal and Marine Geology Program. The USGS Washington Water Science Center provided field and laboratory support. Greg Justin (retired USGS) and Angela Tan assisted with September 2015 sediment collection; Elena Chapman, James Foreman, Joe Morgan, Karen Payne, Norm Peterson, Katie Rosa, Craig Senter, Evan Sutton, and Alison Tecca assisted with February 2016 sediment collection. Bob Black and Jennifer Lanksbury provided suggestions that improved this manuscript.

\section{References Cited}

Barrick, R.C., and Prahl, F.G., 1987, Hydrocarbon geochemistry of the Puget Sound Region-III. Polycyclic aromatic hydrocarbons in sediments: Estuarine, Coastal and Shelf Science, v. 25, p. 175-191.

Black, R.W., Barnes, A., Elliot, C., and Lanksbury, J., 2018, Nearshore sediment monitoring for the Stormwater Action Monitoring (SAM) Program, Puget Sound, western Washington: U.S. Geological Survey Scientific Investigations Report 2018-5076, 53 p., https://doi.org/10.3133/ sir20185076.

Conn, K.E., Black, R.W., Vanderpool-Kimura, A.M., Foreman, J.R., Peterson, N.T., Senter, C.A., and Sissel, S.K., 2015, Chemical concentrations and instantaneous loads, Green River to the Lower Duwamish Waterway near Seattle, Washington, 2013-15: U.S. Geological Survey Data Series 973, 46 p., https://doi.org/10.3133/ds973.

Crecelius, E.A., Bothner, M.H., and Carpenter, R., 1975, Geochemistries of arsenic, antimony, mercury, and related elements in sediments of Puget Sound: Environmental Science and Technology, v. 9, no. 4, p. 325-333.

Dutch, M., Partridge, V., Weakland, S., Welch, K., and Long, E., 2009, Quality assurance project plan-The Puget Sound assessment and monitoring program sediment monitoring component: Washington State Department of Ecology Publication 09-03-121, $98 \mathrm{p}$.

Folk, R.L., and Ward, W.C., 1957, Brazos River bar [Texas]; a study in the significance of grain size parameters: Journal of Sedimentary Research, v. 27, no. 1, p. 3-26.

Granek, E.F., Conn, K.E., Nilsen, E.B., Pilsbury, L., Strecker, A., Rumrill, S.S., and Fish, W., 2016, Spatial and temporal variability of contaminants within estuarine sediments and native Olympia oysters-A contrast between a developed and an undeveloped estuary: Science of the Total Environment, v. 557-558, p. 869-879.

Lanksbury, J., Lubliner, B., Langness, M., and West, J., 2017, Stormwater action monitoring 2015/16 mussel monitoring survey: Washington Department of Fish and Wildlife Report FPT 17-06, $115 \mathrm{p}$.

Long, E.R., MacDonald, D.D., Smith, S.L., and Calder, F.D., 1995, Incidence of adverse biological effects within ranges of chemical concentrations in marine and estuarine sediments: Environmental Management, v. 19, no. 1, p. 81-97. 
Luoma, S.N., 1989, Can we determine the biological availability of sediment-bound trace-elements?: Hydrobiologia, v. 176 , p. 379-396.

Norton, D., Serdar, D., Colton, J., Jack, R., and Lester, D., 2011, Control of toxic chemicals in Puget Sound-Assessment of selected toxic chemicals in the Puget Sound Basin: Washington State Department of Ecology Publication 11-03-055, $295 \mathrm{p}$.

Takesue, R.K., 2019, Inorganic compositional data for finegrained Puget Sound sediment along the Burlington Northern Santa Fe rail line, September 2015: U.S. Geological Survey data release, https://doi.org/10.5066/P9JCJ4EQ.

Tobiszewski, M., and Namiesnik, J., 2012, PAH diagnostic ratios for the identification of pollution emission sources: Environmental Pollution, v. 162, p. 110-119.

Toxic Cleanup Program, 2013, Sediment Management Standards, Chapter 173-204 WAC: Washington Department of Ecology Publication 13-09-055, 135 p.

Wade, T.L., Sericano, J.L., Gardinali, P.R., Wolff, G., and Chambers, L., 1998, NOAA's 'Mussel Watch' ProjectCurrent use organic compounds in bivalves: Marine Pollution Bulletin, v. 37, no. 1-2, p. 20-26.

Yunker, M.B., Macdonald, R.W., Vingarzan, R., Mitchell, R.H., Goyette, D., and Sylvestre, S., 2002, PAHs in the Fraser River basin - A critical appraisal of PAH ratios as indicators of PAH source and composition: Organic Geochemistry, v. 33, p. 489-515.
Menlo Park Publishing Service Center

Manuscript approved August 5, 2019

Edited by Monica Erdman

Layout by JoJo Mangano 


\section{$\frac{\mathbb{3}}{3}$}

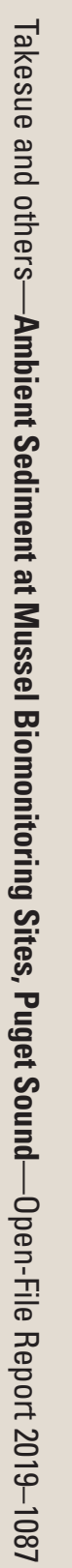

